\title{
Atualidade da obra de Egon Schaden no CENTENÁRIO DE SEU NASCIMENTO
}

\author{
Tânia Welter ${ }^{a}$ e Pedro Martins ${ }^{b}$
}

Em uma entrevista concedida à Mariza Corrêa (1984), Egon Schaden recomendava a "antropologia do vovô" - referindo-se à necessidade de se retornar sempre aos clássicos. A republicação do texto "Problemas fundamentais e estado atual das pesquisas sobre os índios do Brasil" traz a possibilidade de refletirmos sobre essa afirmação. Possibilita, ainda, uma chamada de atenção para a importância e singularidade desse que foi um dos pioneiros da Antropologia no Brasil, tendo atuado de maneira decisiva para a consolidação da disciplina na Universidade de São Paulo.

Filho do imigrante alemão Francisco Schaden, Egon Schaden nasceu em 4 de julho de 1913, na localidade de São Bonifácio, a 80 quilômetros de Florianópolis, Santa Catarina - o que o torna, provavelmente, o único antropólogo brasileiro de grande destaque de origem genuinamente rural, tanto do ponto de vista espacial quanto do ponto de vista de classe (MARTins; Welter, 2013). Sua vocação para a Antropologia e para os estudos indigenistas, segundo seus registros, surgiu quando ainda era criança, na oportunidade em que teve contato com indígenas massacrados e mutilados por bugreiros na encosta da Serra Geral, no entorno de sua área de sociabilidade. Menino pobre, Egon foi beneficiado por uma bolsa de estudo em um colégio jesuíta em Florianópolis, o que lhe garantiu uma sólida formação para continuar seus estudos em São Paulo e construir uma carreira na USP, iniciada junto com a fundação da própria universidade.

Definia-se mais como professor do que como pesquisador, embora um professor empenhado na formação de pesquisadores e na prospecção de problemas de pesquisa relevantes. Sua obra fundamental concentra-se em três teses desenvolvidas na construção de sua carreira acadêmica (LARAIA, 2013). A tese de doutorado, concluída em 1945, trata da mitologia heroica de tribos indígenas do Brasil, sendo publicada pela primeira vez no ano seguinte (Schaden, 1946). Sua tese de livre docência, Aspectos fundamentais da cultura guarani (SCHADEN, 1954), é resul-

a Doutora em Antropologia Social pela Universidade Federal de Santa Catarina (UFSC) e professora da Universidade Federal da Fronteira Sul (UFFS).

b Doutor em Antropologia pela Universidade de São Paulo (USP) e professor da Universidade do Estado de Santa Catarina (UdEsc). 
tado de sua primeira grande pesquisa empírica, ao passo que sua tese de cátedra, Aculturação indígena (SCHADEN, 1965), conduz-no ao refinamento teórico segundo as ideias dominantes na época.

A tese sobre os guaranis tem importância que transcende as fronteiras do país e faz de Egon Schaden um dos mais importantes nomes nessa área (MELLí, 1992). Antes das teses, no entanto, Egon Schaden já havia se manifestado como autor, ao publicar uma cartilha para o ensino de Língua Alemã (SCHADEN, 1937), disciplina da qual foi professor por muitos anos. Em parceria com Gioconda Mussolini, publica importante obra, Povos e trajes da América Latina (1947), além de organizar duas coletâneas de textos científicos (1972 e 1976) com a finalidade de apoiar o ensino da Antropologia na USP e em outras partes do Brasil. Seus artigos, que somam centenas, foram publicados em diferentes idiomas e em periódicos de diferentes países, carecendo ainda de um criterioso inventário.

Como professor, atuou na área de Ciências Sociais da USP, de 1942 a 1967, primeiro como assistente de Emílio Willems e depois como seu sucessor na cátedra de Antropologia. Foi professor visitante em uma dezena de países, incluindo o Japão, principalmente após sua primeira aposentadoria, em 1967. Foi chamado a participar da estruturação da ECA, quando criou a cadeira de Antropologia da Comunicação e lá permaneceu até sua aposentadoria compulsória, em 1983.

$\mathrm{Na}$ época em que proferiu a palestra aqui referenciada, publicada no ano seguinte, Egon Schaden estava passando dos quarenta anos e encontrava-se no ápice de sua atividade intelectual e profissional. Em 1953, havia criado na USP a Revista de Antropologia, a mais antiga da área no país, tendo estabelecido em torno dela diferentes diálogos com pesquisadores brasileiros e estrangeiros.

Sua sólida formação acadêmica e o amplo domínio de línguas (as duas línguas nativas, português e alemão, mas também inglês, francês, espanhol, guarani e esperanto) tornaram possível o acesso à principal bibliografia disponível na época e, também, o diálogo direto e em pé de igualdade com os pensadores contemporâneos em sua área de conhecimento - como o faz no texto aqui publicado. É assim que questiona com desenvoltura as premissas de George Murdock em relação à ideia de área cultural e soma-se a Juan Comas no combate à ideia de raça, embora partilhasse ainda da ideia de aculturação - paradigma dominante na época e que cairá em desuso em meados dos anos 1960. Seu diálogo, pessoalmente ou mediado pela bibliografia, com Claude Lévi-Strauss, George Murdock, Karl von den Steinen ou Juan Comas sempre se deu nas línguas nativas desses pesquisadores. Não é de graça que o texto traz recomendações de pesquisa ao próprio Lévi-Strauss, em 
que se pode constatar uma postura de humildade ou reserva, características de seu comportamento discreto.

Na recomendação, sugere que os trabalhos sobre a mitologia de índios brasileiros não satisfazem "as exigências científicas modernas" e deixa de citar seu próprio trabalho de doutorado, obra ainda hoje não superada ou tornada obsoleta - como era seu desejo, manifesto na nota à terceira edição de Mitologia heroica, de 1988.

Se há alguma ressalva ao trabalho de Egon Schaden, ela se resume ao emprego da ideia de "aculturação", que, como já dito, era um paradigma dominante na época e caiu em desuso anos mais tarde. Sobre isso, de qualquer forma, afirmava o antropólogo que não estava preocupado com as modas teóricas, mas com os problemas de pesquisa concretos e com a etnografia - isso, afirmava, sempre pode ser retomado e revisto por outros pesquisadores, talvez com melhores paradigmas e com mais propriedade.

No ano em que se completa um centenário de nascimento de Egon Schaden, a republicação de um texto seu, com um inventário da produção científica da época da consolidação da Antropologia enquanto disciplina acadêmica, é especialmente relevante para mostrar sua atualidade. O texto, como toda a sua obra, é um verdadeiro repertório de erudição, decorrência da sólida formação obtida em casa, na escola primária, no Colégio Catarinense e na Faculdade de Filosofia, Letras e Ciências Humanas da USP.

Ainda na já citada entrevista de Egon Schaden concedida à Mariza Corrêa, em que recomendava a "antropologia do vovô", o antropólogo constatava que "cada vez mais os jovens estão se dando conta disto", estão sempre voltando o olhar para as produções originais e para os precursores da disciplina, o que é confirmado pela publicação de seu texto nesta edição, bem como pelo grande debate suscitado nas comemorações da passagem do centenário de seu nascimento.

\section{REFERÊNCIAS BIBLIOGRÁFICAS}

CorrêA, Mariza. Entrevista com Egon Schaden. Campinas: Arquivos da Unicamp, 1984.

LaraiA, Roque de Barros. A etnologia de Egon Schaden. Revista de Antropologia, v. 1, n. 56, p. 427-439, 2013.

Martins, Pedro; Welter, Tânia. Egon Schaden - um alemão catarinense. Revista de Antropologia, v. 1, n. 56, p. 441-468, 2013.

Melliá, Bartomeu. Egon Schaden: um nome na etnologia Guarani. Revista USP, n.13, p. 74-77, mar./maio 1992. 
Schaden, Egon. Pequena gramática alemã. São Paulo: Saraiva, 1937.

. A mitologia heroica de tribos indígenas do Brasil. São Paulo: EdusP, 1946. . Aspectos fundamentais da cultura guarani. São Paulo: EPU/EdusP, 1954. . Aculturação indígena. Revista de Antropologia, São Paulo, n. 13, 1965.

. Homem, cultura e sociedade no Brasil. Petrópolis: Vozes, 1972.

. Leituras de etnologia brasileira. São Paulo: Companhia Editora Nacional, 1976.

; Mussolini, Gioconda. Povos e trajes da América Latina. São Paulo: Melhoramentos, 1947. 